Jurnal Penelitian dan Evaluasi Pendidikan

\title{
DIFUSI KEBIJAKAN PENGARUSUTAMAAN GENDER PADA INDIVIDU: REFLEKSI TERHADAP METODE PENELITIAN DIFUSI
}

\author{
Mami Hajaroh \\ Prodi Kebijakan Pendidikan FIP UNY \\ Jl. Colombo No.1 Yogyakarta 55281 \\ mami_hajaroh@yahoo.com
}

\begin{abstract}
Abstrak
Penelitian ini bertujuan untuk menemukan model konseptual difusi kebijakan, faktor-faktor penentu adopsi, dan metode penelitian difusi pengarusutamaan gender (PUG). Penelitian menggunakan pendekatan kualitatif fenomenologi dengan subjek Fatayat NU di DIY. Data dikumpulkan dengan interview mendalam dengan triangulasi tema-tema. Analisis data menggunakan Interpretive Phenomenology Analysis (IP A) dan Event History Analysis (EHA). Hasil penelitian menunjukkan bahwa model konseptual difusi kebijakan pada individu ditemukan dengan tahap pengetahuan, persuasi, konfirmasi, keputusan dan implementasi. Adopsi kebijakan PUG pada individu ditentukan oleh faktor internal meliputi latar belakang individu, keinovatifan sesuai dengan kebutuhan individu, dan perilaku aktif dari individu dan faktor penentu eksternal meliputi ketersediaan sumber dan saluran informasi, Anggota Kelompok (Member group), Kelompok Referensi (Reference group). Penelitian difusi kebijakan pada individu menggambarkan sebuah proses mental yang kompleks yang membutuhkan kajian interdisipliner berbagai bidang ilmu.
\end{abstract}

Kata kunci: pengarusutamaan gender, difusi, adopsi, kebijakan, metode penelitian 


\title{
THE DIFFUSION OF THE GENDER MAINSTREAMING POLICY IN INDIVIDUALS: \\ A REFLECTION ON THE DIFFUSION RESEARCH METHOD
}

\author{
Mami Hajaroh \\ Prodi Kebijakan Pendidikan FIP UNY \\ Jl. Colombo No.1 Yogyakarta 55281 \\ mami_hajaroh@yahoo.com
}

\begin{abstract}
This study aims to find out a conceptual model for the diffusion of a policy, adoption determinant factors, and a research method for the gender mainstreaming diffusion. This study employed the phenomenological qualitative approach involving the members of Fatayat NU in Yogyakarta Special Territory. The data were collected through in-depth interviews using theme triangulation. The data were analyzed using the Interpretive Phenomenology Analysis (IPA) and Event History Analysis (EHA). The research findings show that that the conceptual model for the diffusion of a policy in individuals is applied through the stages of knowledge, persuasion, confirmation, decision, and implementation. The adoption of the gender mainstreaming policy in individuals is determined by internal factors, including the individual's backgrounds, the innovativeness in accordance with the individual's needs, and the individual's active behaviors, and by external factors, including the availability of information sources and channels, member groups, and reference groups. A study on the diffusion of a policy in individuals describes a very complex mental process that needs interdisciplinary studies involving a variety of sciences.
\end{abstract}

Keywords: gender mainstreaming, diffusion, adoption, policy, research method 
Jurnal Penelitian dan Evaluasi Pendidikan

\section{Pendahuluan}

Kebijakan merupakan arah tindakan yang disusun untuk memberikan perubahan pada masyarakat ke arah yang lebih baik. Baik perubahan dalam bidang-bidang tertentu seperti pendidikan, ekonomi, politik, maupun perubahan masyarakat yang lebih luas. Kebijakan baru sebagai upaya memberikan perubahan dapat disebut sebagai inovasi karena di dalamnya terdapat gagasan baru yang dengannya menjadi pangkal tolak terjadinya perubahan. Difusi kebijakan baru (inovasi) kepada masyarakat pengguna inovasi menjadi sesuatu yang penting, tetapi difusi inovasi sering tidak semudah dan selancar pembuatan kebijakan (penciptaan inovasi). Jika perubahan dalam masyarakat diinginkan terjadi dengan adanya kebijakan baru maka difusi menjadi sarana yang paling menentukan dalam perubahan masyarakat. Dalam pembangunan pasti mengharapkan masyarakat berubah maju dengan difusi inovasi yang diinginkan.

Gerakan perempuan dunia mengglobal dan mempengaruhi gerakan perempuan pada seluruh belahan dunia melalui difusi ide-ide, gagasan dan kebijakan yang mereka ciptakan, termasuk Indonesia. Gerakan perempuan dunia yang muncul menyebarkan ide-ide, gagasan dan kebijakan ini dimotori oleh perempuan di Barat dengan membawa nilai-nilai yang sangat berbeda dengan nilai-nilai Timur (Indonesia). Gerakan perempuan yang mengusung kesetaraan dan keadilan gender menjadi wacara baru di Indonesia pada tahun 1970-an dan dihadapi oleh gerakan perempuan Indonesia yang nota bene memiliki nilai-nilai ketimuran yang religius.

Kebijakan pengarusutamaan gender (Gender Mainstreaming) merupakan kebijakan global sebagai strategi pembangunan merupakan inovasi kebijakan dalam rangka perubahan kehidupan yang berkeadilan dan berkesetaraan gender di deklarasikan pada tahun 2000 di Beijing. Strategi pengarusutamaan gender didifusikan melintas negara sampai ke Indonesia dan diadopsi dengan dikeluarkan Instruksi Presiden RI No.9 Tahun 2000 tentang Pengarusutamaan Gender (Gender Mainstreaming) dalam Pembangunan Nasional pada Tanggal 19 Desember 2000. Kebijakan pengarusutamaan gender menuntut peran perempuan yang lebih besar dalam berbagai sektor pembangunan, termasuk dalam lembaga legislatif, eksekutif 
dan yudikatif. Keberhasilan strategi pengarusutamaan gender dalam mengubah kehidupan masyarakat sangat ditentukan oleh difusi yang dilakukan.

Hal yang menarik dalam gerakan organisasi Fatayat NU adalah bergerak secara progresif bekerja sama dengan lembaga donor dalam berbagai aktivitas pelaksanaan program mewujudkan pengarusutamaan gender. Gerakan ini dilakukan oleh Pimpinan Pusat Fatayat NU di tingkat Nasional yang nota bene para anggota pengurus di tingkat Pucuk Pimpinan berpendidikan tinggi dan memiliki akses yang besar dan berkemampuan untuk berkomunikasi dengan gerakan perempuan internasional. Lalu bagaimana Pucuk Pimpinan ini mendifusikan ide dan gagasan gender maintreaming kepada anggota Fatayat NU pada tingkat di bawahnya, tingkat Pimpinan Wilayah, Pimpinan Cabang, Pimpinan Anak Cabang dan Pimpinan Ranting Fatayat NU yang sebagian besar masih terbelenggu budaya patriarkhi dan patronase?

Ketika memberikan perubahan melalui difusi membutuhkan pendekatan atau strategi yang tepat dan berlangsung dari waktu-waktu. Dengan strategi yang tepat dan relevan dengan sasaran difusi yakni individu-individu dalam organisasi atau lembaga maka kebijakan baru atau inovasi akan diterima. Difusi yang dilakukan pada individu diharapkan berdampak pada organisasi atau lembaganya. Untuk bisa meneliti mengenai difusi kebijakan pengarusutamaan gender pada individu dan organisasi juga memunculkan permasalahan mengenai apa dan bagaimana metode penelitian difusi yang akan digunakan mengingat penelitian difusi merupakan bagian dari pendekatan $R, D$ and $D$ (Research, Development and Difusion) belum banyak dikembangkan.

Studi difusi dan inovasi kebijakan telah diadopsi oleh Walker (1969: 881) dengan mendefinisikan inovasi kebijakan adalah sebuah program atau kebijakan yang baru diadopsi oleh suatu pemerintahan. Tidak dipentingkan apakah kebijakan itu sudah lama ataupun sudah banyak diadopsi oleh pemerintah negara-negara lain. Dengan demikian, perubahan kebijakan dipandang sebagai baru dalam pemerintahan yang menetapkan perubahan, sekalipun perubahan telah diadopsi oleh pemerintah negara-negara lainnya. Rogers (1995, 2003:12) menyebutkan bahwa inovasi adalah suatu ide, praktik atau objek yang dianggap sebagai sesuatu yang baru oleh seorang 
individu atau satu unit adopsi lain. Inovasi menurut Havelock (tth: 2-1) adalah membuat keputusan perubahan dan dengan sikap penuh harapan untuk memperbaiki cara melakukan sesuatu dengan menggunakan sesuatu yang baru.

Pengarusutamaan gender (PUG) sebagai kebijakan baru merupakan inovasi untuk mengatasi masalah yang berkaitan dengan relasi antara lakilaki dan perempuan. Perbedaan laki-laki dan perempuan telah digugat karena dipandang relasi antara keduanya telah menimbulkan ketidakadilan dan ketidaksetaraan yang lebih banyak berdampak negatif terhadap perempuan. Oleh karena itu, diperlukan kebijakan guna mengatasi masalah tersebut dengan tujuan keadilan dan kesetaraan gender. Strategi pembangunan pengarusutamaan gender ini untuk memastikan bahwa laki-laki dan perempuan (1) berpartisipasi yang sama dalam proses pengambilan keputusan dan kebijakan, (2) mempunyai akses yang sama terhadap sumber daya, (3) memiliki peluang yang sama dalam melakukan kontrol terhadap pembangunan, (4) memperoleh manfaat yang sama dalam pembangunan. Dengan strategi pengarusutamaan gender, maka kesenjangan gender dapat dipersempit bahkan ditiadakan sehingga tercapai kesetaraan dan keadilan gender.

Strategi pengarusutamaan gender (Minister of Women Empowerment, 2002: 8) diperluas pada responsif gender (Gender-Responsif) dalam pengembangan kebijakan, program, proyek, dan aktivitas yang mempersempit kesenjangan gender yang mendorong pada perwujudan kesetaraan dan keadilan gender (equality and equity gender). Responsif gender adalah perencanaan yang disusun dengan mengintegrasikan pengalaman-pengalaman, cita-cita, isu-isu dan kebutuhan-kebutuhan yang berbeda-beda dari laki-laki dan perempuan dalam proses formulasi kebijakan. Untuk itu, dalam menyusun perencanaan yang responsif gender penting untuk melengkapinya dengan analisis gender pada setiap pengembangan kebijakan, program, proyek dan aktivitas. Makna dari kebijakan adalah semua kebijakan dan makro, kebijakan nasional, kebijakan provinsi dan kebijakan regional.

Difusi menurut Rogers (1995, 2003: 5-6) adalah proses saat inovasi dikomunikasikan melalui saluran tertentu dari waktu ke waktu pada anggota-anggota dari sebuah sistem sosial. Difusi merupakan suatu tipe yang 
spesial dari komunikasi pesan yang berkaitan dengan ide-ide baru. Di samping itu, difusi juga dapat dianggap sebagai suatu jenis perubahan sosial yaitu suatu proses perubahan yang terjadi dalam struktur dan fungsi sistem sosial. Jelas disini bahwa istilah difusi tidak terlepas dari kata inovasi. Tujuan utama proses difusi adalah diadopsinya suatu inovasi oleh anggota sistem sosial tertentu. Anggota sistem sosial dapat berupa individu, kelompok informal, organisasi dan atau subsistem. Difusi inovasi ini terjadi dalam suatu sistem sosial yang di dalamnya terdapat struktur sosial, individu atau kelompok individu, dan norma-norma tertentu. Secara teoretis teori difusi inovasi menggambarkan pola-model adopsi, menjelaskan mekanisme terjadinya inovasi dan membantu memprediksi apakah difusi akan berhasil.

Berkaitan dengan itu, Damanpour (1996: 694) menyatakan bahwa inovasi dapat dipelajari pada level firma, industri atau level individual. Inovasi pada level organisasi didefinisikan sebagai adopsi ide-ide atau perilaku baru bagi organisasi pengadopsi (Daft 1978, Damanpour and Evan 1984). Adopsi inovasi mengandung arti sebagai sebuah proses dikembangkan dan diimplementasikannya ide-ide dan perilaku baru yang masuk pada satu generasi. Inovasi selain bermakna perubahan pada organisasi, juga sebuah respon perubahan pada lingkungan eksternal organisasi. Inovasi didefinisikan secara luas dengan menekankan pada beberapa tipe, termasuk produk atau layanan baru, teknologi baru, dengan struktur organisasi atau sistem administrasi atau yang berkaitan dengan rencana-rencana dan program baru pada organisasi.

Secara umum terdapat dua klasifikasi besar dalam penelitian difusi inovasi yakni level makro (Macro-Level/ Aggregate) dan (Micro Level/Individua). Makro adalah difusi yang menguji agregasi pasar dan asumsi homogenitas dalam populasi adopter. Secara spesifik fokus pada perilaku adopter individual dan diasumsikan bahwa adopsi inovasi mendasar pada setiap individu yang berbeda dan individu adalah personal yang pelik (Yalcinkaya, 2007: 10). Mengenai tahapan dalam proses memutuskan untuk menerima inovasi (adopsi inovasi) pada level individu. Rogers (1995, 2003: 168-179) menjelaskan dalam 5 tahap yakni: dan knowledge, persuasion, decision, implementation dan confirmation. 
Dalam studi kontemporer tentang implementasi kebijakan memiliki 3 dimensi yakni kebijakan, orang-orang dan tempat (policy, people, place).

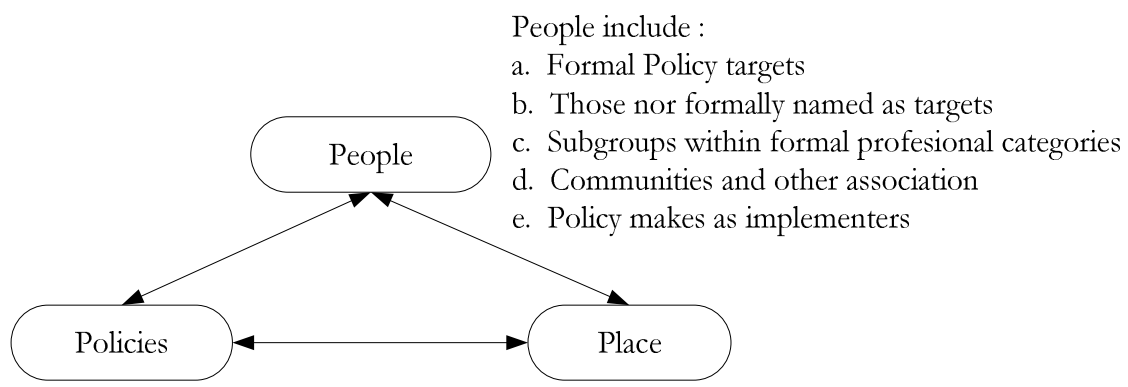

Policy dimention include :

a. Goal

b. Targets

c. Tools
Place vary by :

a. Focal Organization, agency or jurisdiction

b. Historical/institutional context

c. Cross-sistem interdependency

Gambar 1. Dimensi-Dimensi Kontemporer Implementasi Kebijakan dalam Praktik dan Penelitian (Honig, 2006:14).

Dimensi-dimensi ini bertujuan untuk mengungkap perbedaan-perbedaan level analistik yang mempengaruhi implementasi kebijakan (Honig, 2006:14). Dimensi-dimensi dalam implementasi kebijakan yang dikemukakan oleh Honig tersebut dapat digunakan dalam memahami dimensi difusi kebijakan. Tiga dimensi implementasi (policy, people, place) secara besamasama membentuk kerangka pemikiran sebagai proses dari situasi dan sangat tidak terduga. Penelitian ini menyelidiki individu-individu (people) yang merupakan salah satu dimensi dari implementasi kebijakan. Individu sebagai target formal dari difusi kebijakan pengarusutamaan gender dalam organisasi Fatayat NU. Individu-individu yang menjadi target formal menjadi kunci bagi implementasi kebijakan PUG dalam organisasi Fatayat NU.

Tiga dimensi (policy, people, place) saling mempengaruhi dalam difusi dan implementasi kebijakan disajikan dalam Gambar 1. ini juga bertujuan untuk mengungkap perbedaan-perbedaan level analistik yang mempengaruhi difusi dan implementasi kebijakan. Terkait dengan hal tersebut, peneli- 
tian ini bertujuan untuk menemukan model konseptual difusi kebijakan, faktor-faktor penentu adopsi, dan metode penelitian difusi pengarusutamaan gender (PUG).

\section{Metode Penelitian}

Penelitian difusi ini menggunakan paradigma konstruktivisme dan pendekatan kualitatif fenomenologi. Analisis data menggunakan Interpretative Phenomenological Analysis (IPA) Analisis dengan tahap (1) reading and rereading, (2) initial noting, (3) developing emergent themes, (4) searching for connections across emergent themes, (5) Moving the next cases, (6) looking for patterns across cases. Analisis fenomenologi dalam bertujuan untuk mengungkap secara detail bagaimana subjek memaknai dunia personal dan sosialnya yang berkaitan dengan PUG. Dengan sasaran utamanya adalah makna berbagai pengalaman, peristiwa, status yang dimiliki oleh subjek serta mengeksplorasi pengalaman personal yang menekankan pada pesepsi atau pendapat mereka menganai PUG.

Subjek penelitian adalah anggota Fatayat NU yang duduk dalam kepemimpinan pada tingkat cabang, wilayah dan pimpinan pusat yang ditentukan dengan sampel teknik sampel bertujuan (purposive sampling) dengan teknik bola salju (snow ball sampling). Objek penelitian adalah difusi kebijakan pengarusutamaan gender pada individu-individu. Teknik pengumpulan data menggunakan in depth interview (interviu mendalam) kepada subjek penelitian.

Penelitian dimulai dari rancangan awal penelitian yang disusun dan dilaksanakan di lapangan dan dilakukan analisis data. Analisis data dilakukan dalam dua aspek, pertama analisis substantif difusi kebijakan pengarusutamaan gender pada individu menghasilkan refleksi substansi difusi kebijakan. Hasil refleksi substantif ini dituangkan dalam dalam bentuk model konseptual Difusi Kebijakan PUG dan Faktor-faktor penentu Adopsi PUG pada individu. Kedua, refleksi terhadap penelitian difusi kebijakan pada individu untuk menemukan metode penelitian difusi yang relevan. Di bawah ini digambarkan alur penelitian. 


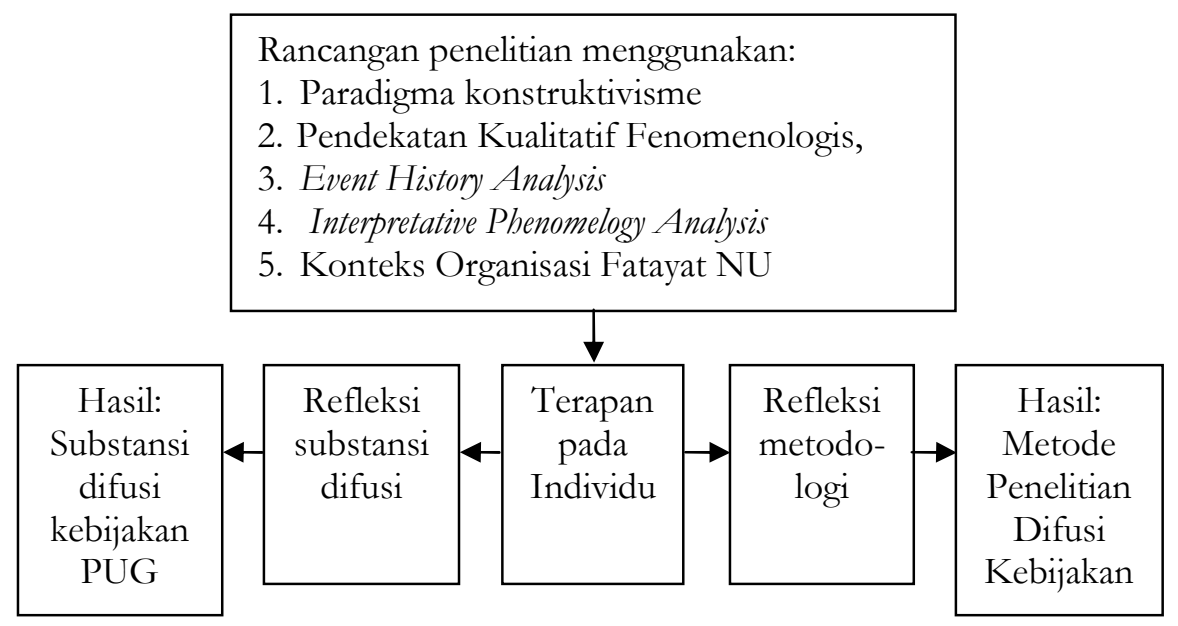

Gambar 2. Alur Penelitian Difusi Kebijakan Pengarusutamaan Gender

\section{Hasil Penelitian dan Pembahasan}

Hasil penelitian ini meliputi dua dimensi yakni difusi kebijakan PUG pada individu dan refleksi terhadap metode penelitian difusi kebijakan. Hasil penelitian dan pembahasan sebagai berikut:

\section{Difusi Kebijakan PUG pada Individu}

Difusi dalam penelitian ini merupakan proses mengkomunikasikan kebijakan PUG kepada individu-individu pengurus yang ditokohkan dalam organisasi Fatayat NU dari tahun 1995-2010. Tahapan difusi kebijakan pengarusutamaan gender yang terjadi pada individu-individu sebagai berikut:

\section{a. Bingung, Ragu-ragu, Kaget, dan Merasa Tercerahkan}

Individu-individu dalam penelitian ini tampak terbuka terhadap informasi tentang kesetaraan dan keadilan gender. Membaca yang dilakukan oleh Marhamah, Amanah, dan Ariyati mengawali perkenalan mereka dengan isu-isu gender dan memberikan kepada mereka kesadaran pengetahuan adanya masalah dalam relasi laki-laki dan perempuan. Buku-buku 
yang membahas tentang gender seperti tulisan Farid Mas'udi, Mansur Fakih, Ashghar Ali, dan novel perempuan berkalung surban tampak memberikan kontribusi dalam menumbuhkan kesadaran pengetahuan tentang gender.

Terbuka terhadap informasi ditunjukkan juga oleh individu-individu dengan kesediaan mereka mengikuti pelatihan-pelatihan yang dilaksanakan oleh berbagai pihak, baik dari Fatayat NU sendiri, elemen lain dari NU bahkan dari pihak luar, seperti pelatihan oleh KPI, YKF, P3M, LKPSM, dan LSIP serta Ford Fondation dan The Asia Foundation yang berasal dari Luar Negeri. Riana, Titis, Labibah, Titi Amah, Susiana, Rosa, maupun Isani pertama kali mendapat informasi tentang kesetaraan dan keadilan gender secara lebih mendalam dari pelatihan yang mereka ikuti.

Respon awal yang diberikan cukup bervariasi dari bingung, raguragu, menolak, takut, dan ada juga yang langsung menerima karena gagasan kesetaran dan keadilan gender dirasakan sebagai sesuatu yang baik, memberikan peluang dan memberikan pencerahan pada diri mereka. Keterbukaan terhadap infomasi menjadi awal yang cukup menentukan bagi diadopsinya kesetaraan dan keadilan pada setiap individu. Hal ini sejalan dengan teori difusi inovasi pada individu bahwa kesadaran pengetahuan terjadi ketika individu atau unit pembuat keputusan terbuka pada keberadaan inovasi dan menambahkan pemahamannya pada bagaimana fungsi inovasi tersebut (Rogers 2003: 169). Pengetahuan merupakan faktor penting untuk terjadinya adopsi kebijakan pengaurusutamaan gender pada individu melalui proses difusi. Pengetahuan dalam arti mengetahui dan mengenal adanya perspektif gender dalam memahami ajaran Islam dan menganalisis persoalan-persoalan sosial masayarakat, serta nilai-nilai kesetaraan dan keadilan gender dalam relasi laki-laki dan perempuan, juga pengetahuan yang bersifat teknis cara melaksanakan kesetaraan dan keadilan gender. Kesadaran pengetahuan diperoleh karena mereka aktif dalam berbagai kegiatan dan forum yang mengkomunikasikan pengaurutamaan gender. Sesuai dengan Rogers, (2003: 171) bahwa individu-individu menambah kesadaran pengetahuan (knowledge-awwareness) tentang inovasi melalui perilaku mereka menginisiasi, sehingga individu-individu itu tidak pasif. 


\section{b. Berpikir Kritis dan Melakukan Refleksi}

Kesadaran pengetahuan ini menumbuhkan persepsi pada individu dengan memberikan penilaian terhadap isu-isu kesetaraan dan keadilan gender yang diangkat oleh gerakan perempuan barat terutama mengenai hak-hak perempuan. Pada tahap ini berpikir kritis dan melakukan tindakan reflektif dilakukan oleh individu-individu. Isu-isu kesetaraan dan keadilan yang diangkat oleh gerakan perempuan baik sebagai metode analisis sosial maupun interpretasi ajaran-ajaran Islam dinilai relevan dengan kebutuhan perempuan dan relatif memberikan keuntungan bagi perempuan. Isu-isu gender yang berkeinginan memberikan perubahan pada ayat-ayat yang telah diyakini qoth'i dalam teks dinilai bertentangan dengan ajaran Islam, dan ini tidak disetujui.

Jika pada tahap sebelumnya yang terjadi adalah proses kegiatan mental yang utama bidang kognitif, maka pada tahap ini afektif atau perasaan mulai berperan untuk memberikan penilaian. Dengan berpikir dan bersikap kritis dan reflektif yang muncul dari keyakinan-keyakinan terhadap kesetaraan dan keadilan gender bergerak menjadi tindakan individu-individu. Individu-individu lalu memberikan penilaian-penilaian yang mendorong mereka untuk menunjukkan kecenderungan sikap setuju atau tidak setuju terhadap kesetaraan dan keadilan gender dengan upaya mereka untuk menginformasikan kepada orang-orang terdekatnya. Pada tahap ini individu-individu melakukan seleksi terhadap informasi yang diterimanya disesuaikan dengan kondisi dan sifat pribadinya. Mereka juga berusaha mengetahui lebih banyak tentang kesetaraan dan keadilan gender dan menafsirkan informasi yang diterimanya serta mengkaji karakteristiknya. Sesuai pendapat Rogers (2000: 175-176) persepsi individu memegang peran penting dalam adopsi inovasi pada tahap persuasi. Melalui proses persepsi ini individu menunjukkan sikap setuju atau tidak setuju pada kesetaraan dan keadilan gender sebagi sebuah inovasi. Konsep kesetaran dan keadilan gender oleh individu-individu dinilai relatif memberikan keuntungan kepada perempuan, memberikan ruang dan peluang yang lebih luas kepada perempuan.

Faktor-faktor yang menentukan kecenderungan sikap setuju dan tidak setuju terhadap kesetaraan dan keadilan gender sebagai berikut: 


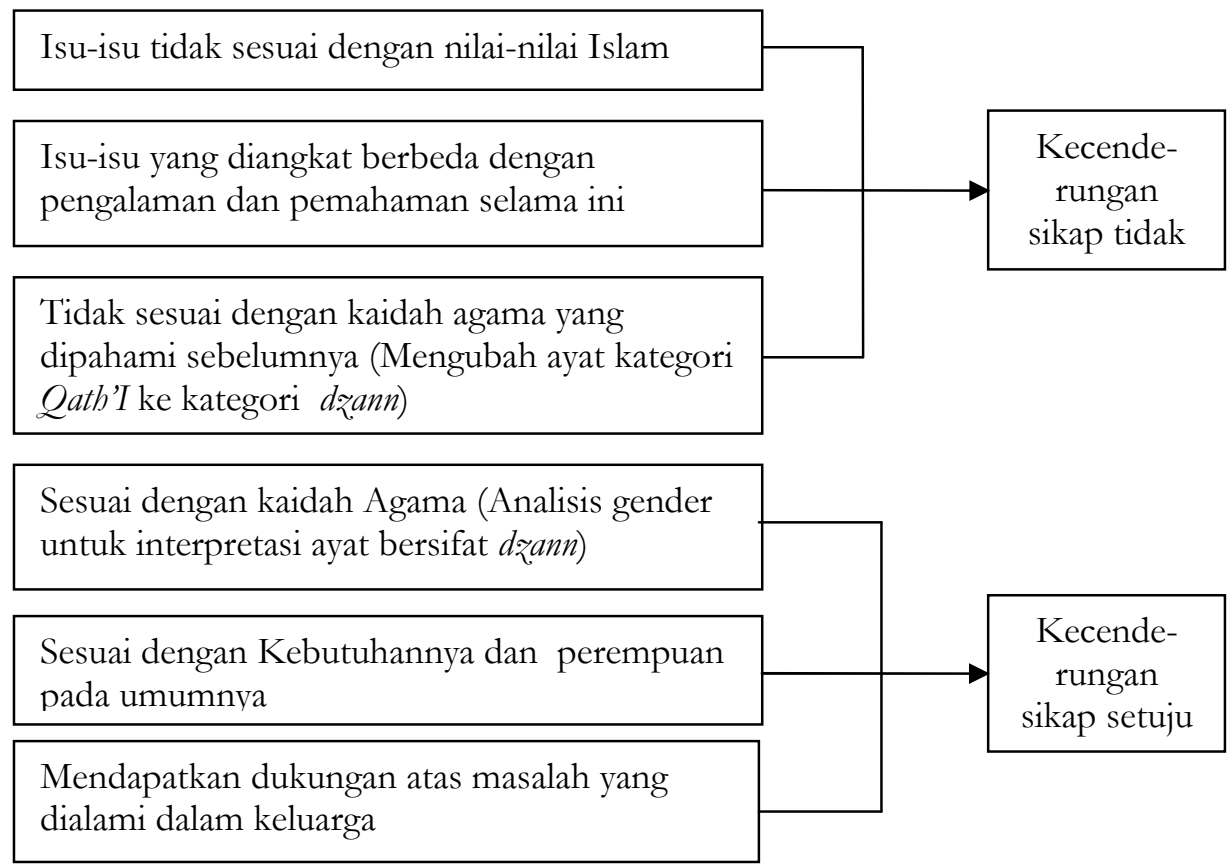

Gambar 3. Faktor-faktor yang Menentukan Individu Bersikap Setuju dan Tidak Setuju terhadap Kesetaraan dan Keadilan Gender.

\section{c. Konfirmasi untuk Penguatan Menerima atau Menolak Inovasi}

Dalam proses memutuskan menerima inovasi sebagai tujuan dari difusi, individu-individu melakukan konfirmasi untuk penguatan atas sikap mereka. Penguatan tersebut membantu individu-individu untuk meyakinkan sikap setuju atau tidak setuju mereka terhadap setiap isu-isu kesetaraan dan keadilan gender. Konfirmasi dilakukan dengan melihat kelompok lain sebagai (reference group). Nilai, norma dan perilaku yang dimiliki oleh kelompok lain dinilai dan ditemukan ada hal-hal baik dan ada hal-hal yang dinilainya buruk. Pada hal-hal yang dinilai baik dan dinilai benar maka ini mendorong individu untuk menerima. Sementara pada nilai, norma dan perilaku yang dinilainya tidak baik karena bertentangan dengan ajaran agama maka ditolak. Konfirmasi kepada kelompoknya (membership groups) 
dilakukan karena ia merupakan anggota dari kelompok dalam hal ini Fatayat NU, sehingga ketika PP Fatayat NU menggulirkan kebijakan dan program untuk kesetaraan dan keadilan gender memperkuat keyakinannya untuk menerima.

Cara-cara melakukan konfirmasi dapat digambarkan sebagai berikut:

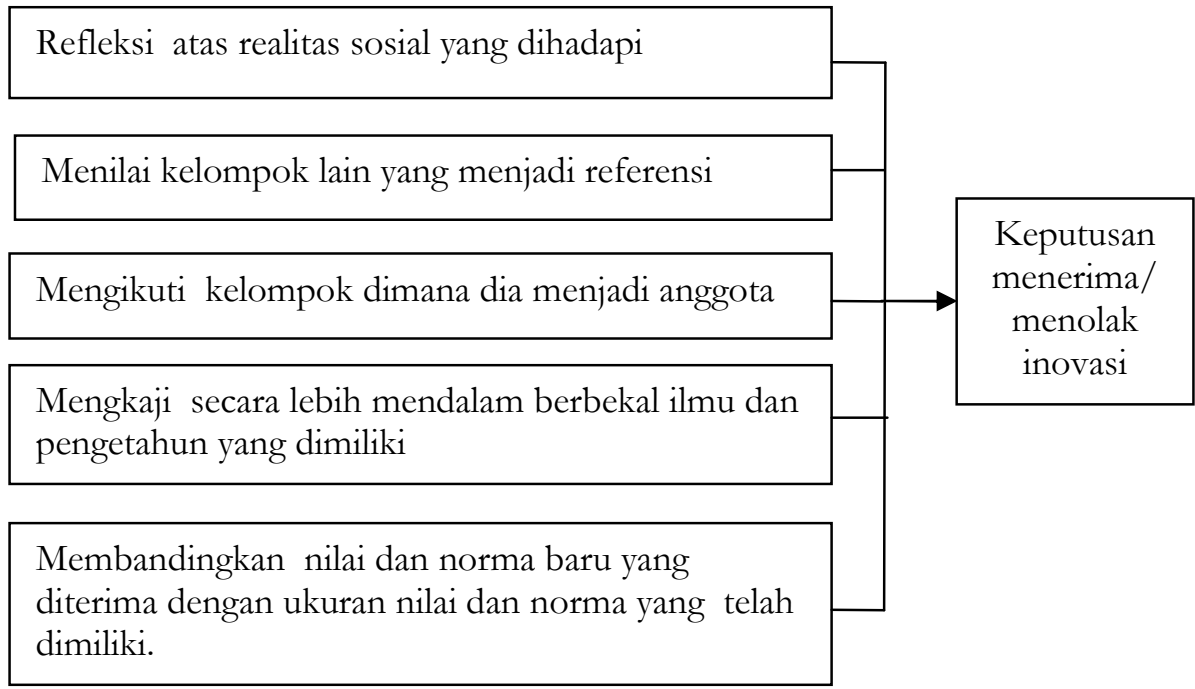

Gambar 4. Cara-cara Melakukan Konfirmasi yang Menentukan Keputusan Menerima atau Menolak Inovasi

Gambar di atas menunjukkan cara yang dilakukan individu dalam upaya melakukan peneguhan atas sikap setuju dan tidak setuju terhadap kesetaraan dan keadilan gender yang menentukan keputusan individu menerima atau menolak inovasi. Caranya dengan melakukan refleksi atas realitas sosial yang dihadapi, menilai kelompok lain yang menjadi referensi, mengikuti kelompok dimana dia menjadi anggota (organisasi Fatayat), mengkaji secara lebih mendalam, membandingkan nilai dan norma yang dimiliki dengan nilai dan norma baru yang diterimanya. Pada tahap ini individu-individu mencari acuan atau referensi untuk mempertajam pertimbangan mereka sebelum memutuskan menerima atau menolak inovasi. 


\section{d. Menginisiasi Perubahan Mulai dari Lingkungan Terdekat}

Pada saat individu-individu membuat keputusan untuk menerima kesetaraan dan keadilan gender mereka memulai dengan aktivitas yang mengarah untuk melaksanakan dalam kehidupannya. Aktivitas melaksanakan dimulai dari lingkungan terdekat yakni keluraga dan atau organisasi Fatayat NU dimana mereka beraktivitas kedua setelah keluarga. Aktivitas menyampaikan gagasan kesetaraan dan keadilan gender dalam keluarga merupakan aktivitas memulai melaksanakan karena implementasi kesetaraan dan keadilan gender mengharuskan keterlibatan pihak lain yang terdekat dalam kehidupannya. Walaupun ada individu yang menerima kesetaraan gender akan tetapi tidak dapat menyampaikan kepada anggota keluarga yang lain karena hambatan situasi dan kondisi dalam keluarganya. Yang lain memiliki peluang yang lebih luas, tidak memulai dari keluarga akan tetapi memberikan pengaruhnya kepada organisasi sebagai wadah untuk memberikan infomasi yang lebih luas kepada anggota. Memulai menginisasi kebijakan dan program organisasi tentang kesetaraan dan keadilan gender dimaksudkan agar dapat lebih meluaskan gagasan kesetaraan dan keadilan gender.

Keputusan menerima kesetaraan dan keadilan gender terjadi pada individu-individu ketika mereka terikat dalam aktivitas yang memandu mereka untuk melakukan aktivitas dalam rangka mewujudkan kesetaraan dan keadilan gender. Sebagaimana Rogers (2003, 2005: 177) menuliskan keputusan terjadi ketika individu atau unit pembuat keputusan terikat dalam aktivitas yang memandu pada pilihan mengadopsi atau menolak inovasi. Pada adopsi kebijakan pengarusutaman gender ini tampak individu-individu menerimanya berarti memiliki niat sepenuhnya dan melakukan tindakan untuk melaksanakan kesetaraan dan keadilan gender dalam kehidupan mereka.

Individu yang menjadi pimpinan organisasi relatif memiliki kepekaan dan kepedulian terhadap masyarakat dalam hal ini anggota organisasi menyadari bahwa anggota Fatayat NU masih berada dalam keterkukungan hegemoni patriarkhi. Hal ini mendorongnya untuk menginisiasi mengimplementasikan isu-isu kesetaraan dan keadilan gender dalam skala yang 
lebih luas yakni menjadi kebijakan organisasi. Upayanya adalah melakukan advokasi agar isu-isu kesetaraan dan keadilan gender dapat menjadi kebijakan organisasi Fatayat NU. Keinginan untuk memberikan perubahan pada masyarakat dengan memberikan intervensi melalui kebijakan organisasi dan tindakan aksi menjadi bagian penting dari proses adopsi dalam organisasi.

\section{e. Model Difusi Konseptual Kesetaraan dan Keadilan Gender pada Individu}

Hasil penelitian menunjukkan bahwa individu-individu menerima kesetaraan dan keadilan gender melalui difusi dengan tahapan pengetahuan, persuasi, konfirmasi, keputusan dan implementasi. Proses mental yang terjadi pada individu-individu diawali proses kognisi, kesadaran pengetahuan terhadap informasi yang diterima menimbulkan persepsi-persepsi pada individu-individu dengan munculnya penilaian-penilaian mereka terhadap kesetaraan dan keadilan gender. Penilaian-penilaian yang mereka berikan menumbuhkan proses persuasi dalam bentuk sikap setuju atau tidak setuju. Namun demikian, kesetujuan dan ketidaksetujuan mereka masih membutuhkan konfirmasi. Konfirmasi dibutuhkan oleh individu-individu untuk memperkuat terhadap apa yang mereka setujui untuk ditindaklajuti dengan keputusan menerima dan mengimplementasikan kesetaraan dan keadilan gender. Penegasan juga dibutuhkan untuk memperkuat ketidaksetujuan mereka ketika menolak pada hal-hal yang dalam penilaian awal mereka bertentangan dengan ajaran Islam. Ditemukan berbagai cara dalam melakukan penegasan atau konfirmasi yang dilakukan oleh individu-individu informan.

Mereka menerima konsep perspektif gender untuk analisis sosial masyarakat dan untuk menginterpretasikan kembali ayat-ayat Alquran yang selama ini diintepretasi bias gender. Mereka juga menerima kesetaraan dan keadilan gender yang memiliki dasar hukum dalam ajaran Islam. Akan tetapi, mereka tidak menerima upaya mengubah klasifikasi ayat-ayat Alquran dari kategori qath'i ke dalam kategori dzann kemudian menginterpretasikan ayat-ayat Alquran yang bersifat qath'i tersebut. Mereka juga 
tidak menerima isu untuk mengubah ayat yang dinilai secara tekstual bias gender.

Keyakinan kebenaran terhadap informasi pada aspek kognisi dengan kesadaran pengetahuan mereka maupun afeksi yang telah mendapatkan peneguhan atau konfirmasi untuk memperkuat sikap, meyakinkan mereka untuk memutuskan menerima atau menolak bagian-bagian dari kesetaraan dan keadilan gender yang digulirkan. Pada isu-isu yang mendapat peneguhan bahwa isu tidak sejalan dengan ajaran Islam maka meyakinkan individuindividu untuk tidak menerimanya. Dengan kata lain, memutuskan menolak inovasi kesetaraan dan keadilan gender yang tidak sesuai dengan nilai, norma dan keyakinan ajaran Islam.

Isu-isu kesetaraan dan keadilan gender yang mendapatkan peneguhan kebenaran semakin meyakinkan mereka untuk memutuskan menerima dan mengimplementasikan melalui aktivitas tindakan mereka di kehidupan sehari-hari. Dengan kata lain, individu-individu memutuskan menerima inovasi yang sesuai dengan nilai, norma dan keyakinan dalam Islam. Keputusan menerima inovasi kesetaraan dan keadilan gender dilanjutkan dengan tindakan nyata untuk mewujudkan dalam lingkungan terdekat mereka yakni keluarga atau organisasi Fatayat NU. Hanya saja untuk menjadi kebijakan dan program organisasi Fatayat NU dilakukan peneguhan atau konfirmasi kepada Nahdlatul Ulama sebagai organisasi induknya.

Difusi isu-isu kesetaraan dan keadilan gender dapat digambarkan dalam model difusi inovasi pada level individu. Model yang ditemukan ini dengan tahap pengetahuan, persuasi, konfirmasi, keputusan dan implementasi. Kemudian ketika individu-individu akan melakukan penyebarluasan (difusi) dalam organisasi atau melalui organisasi mereka melakukan konfirmasi kembali. Konfirmasi ini dimaksudkan untuk mendapatkan peneguhan dari organisasi induk (Nahdlatul Ulama) agar organisasi Fatayat NU direstui untuk melakukan difusi pada level organisasi. Tahap dalam model ini berbeda dengan model difusi pada individu yang dikemukakan oleh Rogers yang dengan tahap pengetahuan, persuasi, keputusan, implementasi dan konfirmasi. 


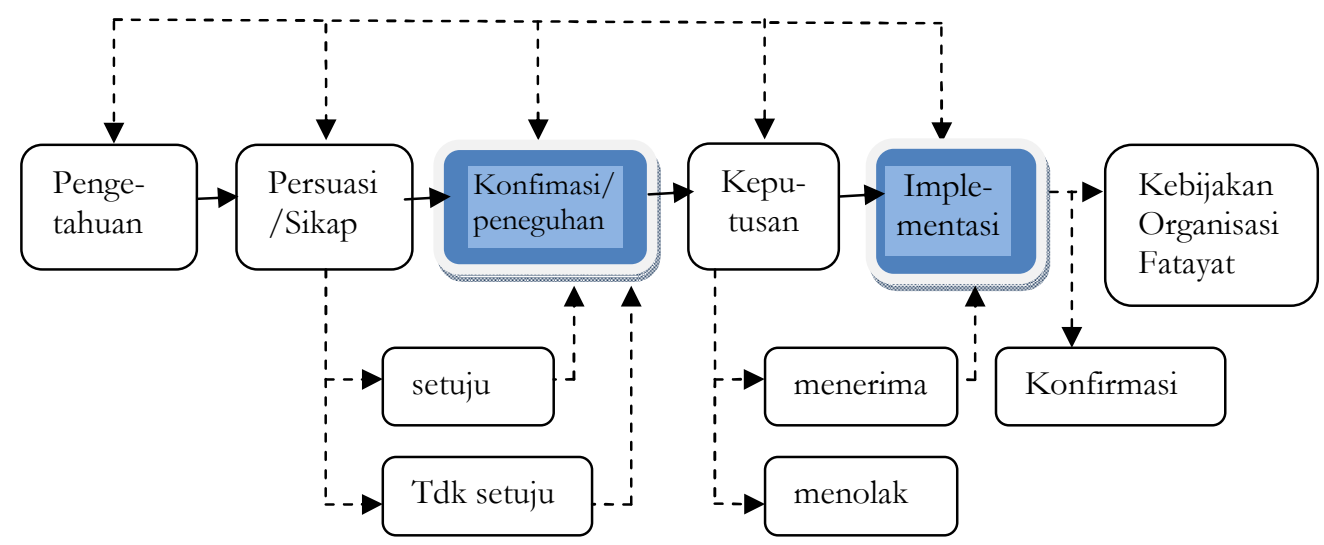

Gambar 5. Model Difusi Inovasi pada Individu

\section{Faktor -faktor Penentu Adopsi Kesetaraan dan Keadilan Gender pada Individu}

Beberapa individu menyatakan bahwa kehidupan di keluarga mereka menggambarkan kehidupan relasi gender yang belum setara dan adil. Kondisi ini pada awalnya dianggap sebagai nilai dan norma yang benar. Akan tetapi setelah menerima informasi mengenai nilai dan norma kesetaraan dan keadilan gender menjadikan mereka sadar dan semakin sadar bahwa relasi gender yang mereka alami dan juga dialami oleh kebanyakan perempuan pada umumnya menyimpan persoalan yang harus diselesaikan.

Kesetaraan dan keadilan gender memiliki karakteristik sebagai inovasi relative memberikan keuntungan kepada perempuan. Dengan itu, perempuan memiliki kesempatan untuk mengembangkan diri baik di ruang domestik maupun publik tanpa harus dihantui oleh rasa bersalah karena apa yang mereka lakukan tidak bertentangan dengan ajaran Islam. Selain itu, sesuai dengan kebutuhan perempuan untuk mengaktualisasikan potensi yang mereka miliki. Perempuan memiliki potensi yang sama dengan lakilaki untuk berkiprah di ruang publik dan domestik. Nilai dan norma kesetaraan dan keadilan bukan nilai dan norma yang sulit dan rumit untuk dilaksanakan dalam kehidupan sehari-hari. 
Dari analisis ini tampak bahwa isu-isu kesetaraan dan keadilan yang digulirkan oleh gerakan perempuan global memiliki karakteristik sebagai inovasi (pembaharuan) yang relatif memberikan keuntungan bagi perempuan, bukan sesuatu yang rumit untuk dilaksanakan, bisa diujicobakan dan praktiknya dapat diamati dalam kehidupan sehari-hari. Walaupun tidak semua isu kesetaraan dan keadilan gender sesuai dengan nilai, norma dan keyakinan mereka, namun masih banyak isu-isu yang sesuai (compatible) dengan dengan nilai, norma dan keyakinan sehingga adopsi terhadap inovasi dapat terjadi dengan proses filterisasi. Karakteristik ini sesuai dengan pendapat Rogers (2003: 170) karakteristik inovasi meliputi relative advantage, compatibility, complexity, trialability, dan obserability.

Karakteristik inovasi kesetaraan dan keadilan gender dapat digambarkan sebagai berikut:

\begin{tabular}{|c|c|}
\hline $\begin{array}{l}\text { Relatif memberikan keuntungan pada } \\
\text { perempuan }\end{array}$ & \\
\hline Sesuai dengan kebutuhan individu-individu & \\
\hline Bukan konsep yang rumit & $\begin{array}{c}\text { Karakteristik } \\
\text { PUG sbg } \\
\text { Inovasi }\end{array}$ \\
\hline $\begin{array}{l}\text { Konsep yang dapat dicobakan dalam } \\
\text { kehidupan keluarga dan masyarakat }\end{array}$ & \\
\hline Dapat diamati dalam kehidupan sehari-hari & \\
\hline
\end{tabular}

Gambar 6. Karakteristik Inovasi Kesetaraan dan Keadilan Gender

Sementara itu, jika dianalisis dari proses adopsi, isu-isu kesetaraan dan keadilan gender pada individu sebagai hasil dari difusi ditentukan oleh berbagai faktor. Karakter internal individu-individu tampak menjadi faktor penentu internal dalam adopsi isu-isu kesetaraan dan keadilan gender. Faktor penentu internal merupakan kondisi internal yang lebih banyak ditentukan oleh kehidupan individu sebelum menerima informasi kesetaraan dan keadilan gender. Kehidupan keluarga yang belum setara dan adil gender 
baik yang telah dirasakan dan disadari sebelumnya maupun yang baru disadari setelah mendapatkan informasi tentang kesetaraan dan keadilan gender. Informasi mampu memberikan kesadaran baru bagi individu atas kehidupan mereka yang kontradiktif.

Adopsi juga ditentukan oleh sifat keinovatifan kesetaraan dan keadilan gender. Kesetaraan dan keadilan merupakan pembaharuan yang mereka butuhkan untuk kehidupan diri mereka sebagai perempuan dan perempuan lainnya ke arah yang lebih setara dan adil. Kesesuaian dengan kebutuhan menjadi faktor penentu internal bagi adopsi terbukti dengan beberapa pernyataan dengan adanaya isu-isu kesetaraan dan keadilan menjadikan perempuan mendapatkan ruang, memiliki peluang untuk meraih kehidupan yang setara dan adil dalam ruang publik maupun domestik.
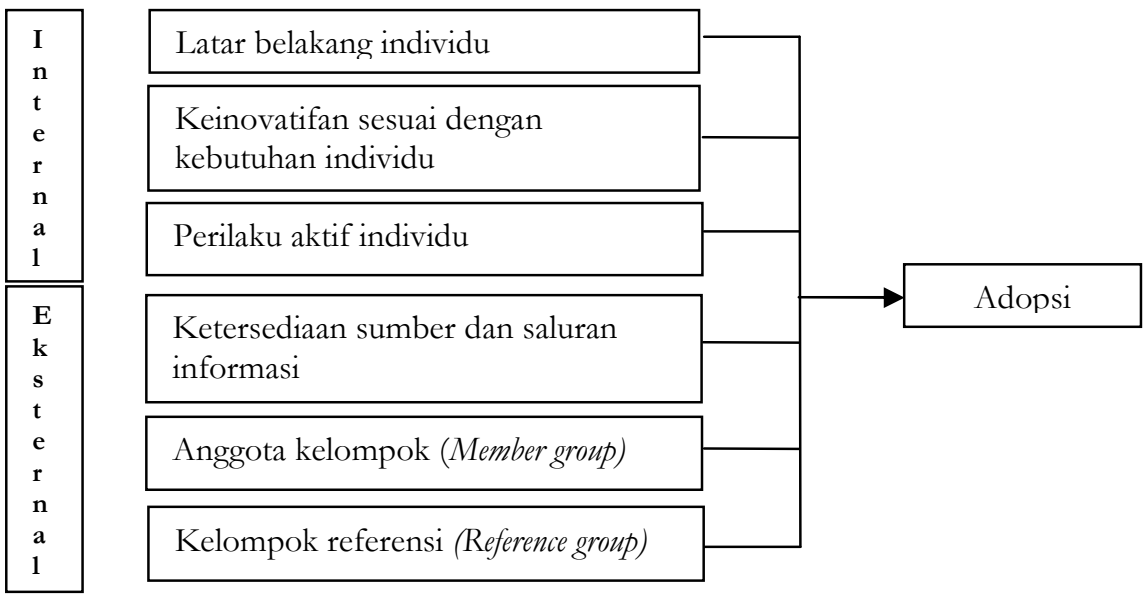

Gambar 7. Faktor-faktor Penentu Adopsi Kesetaraan dan Keadilan Gender Pada Individu

Karakter aktif yang dimiliki oleh individu untuk mau mencari dan menerima peluang mendapatkan informasi menjadi faktor penentu internal. Tidak pernah menolak ketika mendapat tawaran untuk pelatihan, mengadakan dan menghadiri diskusi-diskusi, membaca buku-buku dan jurnal tentang gerakan kesetaraan dan keadilan menunjukkan perilaku aktif mereka. Faktor internal ini didukung pula oleh peluang akses informasi 
sebagai faktor eksternal yang mampu menjawab dan memberi jawaban atas sifat aktif mereka dalam mencari informasi. Maraknya penerbitan bukubuku feminis pada tahun 1996-2000 menjadi sumber informasi bagi mereka. Komunikasi interpersonal dalam pelatihan dengan narasumber juga menentukan bagi diadopsi atau ditolaknya inovasi. Banyaknya LSM dan organisasi yang menggelar pelatihan gender menjadi saluran informasi yang menentukan bagi adopsi inovasi.

Konfirmasi yang dilakukan menentukan keputusan mereka untuk menerima atau menolak inovasi. Konfirmasi dari organisasi tempat mereka menjadi anggota dan merasa terikat menjadi faktor penentu eksternal dari adopsi inovasi. Isu-isu yang digulirkan oleh PP Fatayat NU menjadi penguatan bagi individu yang menolak ketika memperoleh informasi sebelumnya. Mereka yang pertama kali memperoleh informasi isu-isu kesetaraan dan keadilan gender dari PP Fatayat NU memberikan respon yang positif dengan menampilkan kecenderungan sikap setuju dan mengadopsinya.

YKF dan KPI tampak sebagai reference groups salah satu faktor penentu eksternal bagi individu-individu yang menentukan dalam proses menerima dan menolak inovasi. Isu-isu kesetaraan dan keadilan gender yang digulirkan oleh kedua grup ini jika sesuai dengan nilai, norma dan keyakinan mereka isu itu diterima dan diimplementasikan. Akan tetapi, pada beberapa yang dinilai liberal oleh individu tidak diterima karena tidak sesuai dengan nilai, norma dan keyakinan mereka. Pada grup referensi individu-individu memilah dan memilih isu-isu yang dapat diterima dan isuisu yang mereka tolak.

\section{Refleksi terhadap Metode Penelitian Difusi pada Individu}

Refleksi terhadap metode penelitian difusi kebijakan PUG pada individu merupakan refleksi metodologis. Peneliti menilai hal ini penting untuk dilakukan dalam rangka mengembangkan metode penelitian difusi kebijakan. Penelitian ini dilakukan pada individu-individu tokoh atau pemimpin organisasi Fatayat NU yang berperan sebagai agen perubahan dalam organisasi khususnya dan masyarakat umumnya. Metode yang dihasilkan dalam refleksi ini relevan untuk meneliti individu yang berperan 
sebagai agen perubahan bukan individu sebagai pengikut pada tataran akar rumput (grassroot).

Penelitian difusi kesetaraan dan keadilan gender pada individu menggambarkan sebuah proses perubahan yang sangat kompleks. Realitas perubahan kognisi dan perilaku pada individu-individu dari kultur patriakhi kepada kultur yang setara dan adil gender mampu membangun pribadi-pribadi yang progresif. Pribadi yang lepas dari keterkungkungan berpikir dan bertindak menjadi pribadi yang kritis dan memiliki kebebasan yang dibingkai oleh nilai, norma dan keyakinan agama Islam. Kompleksitas ditemukan dalam penelitian difusi adalah dalam analisis membutuhkan kajian dari berbagai disiplin ilmu. Kompleksitas penelitian difusi kebijakan pada individu dapat dilihat Gambar 6.

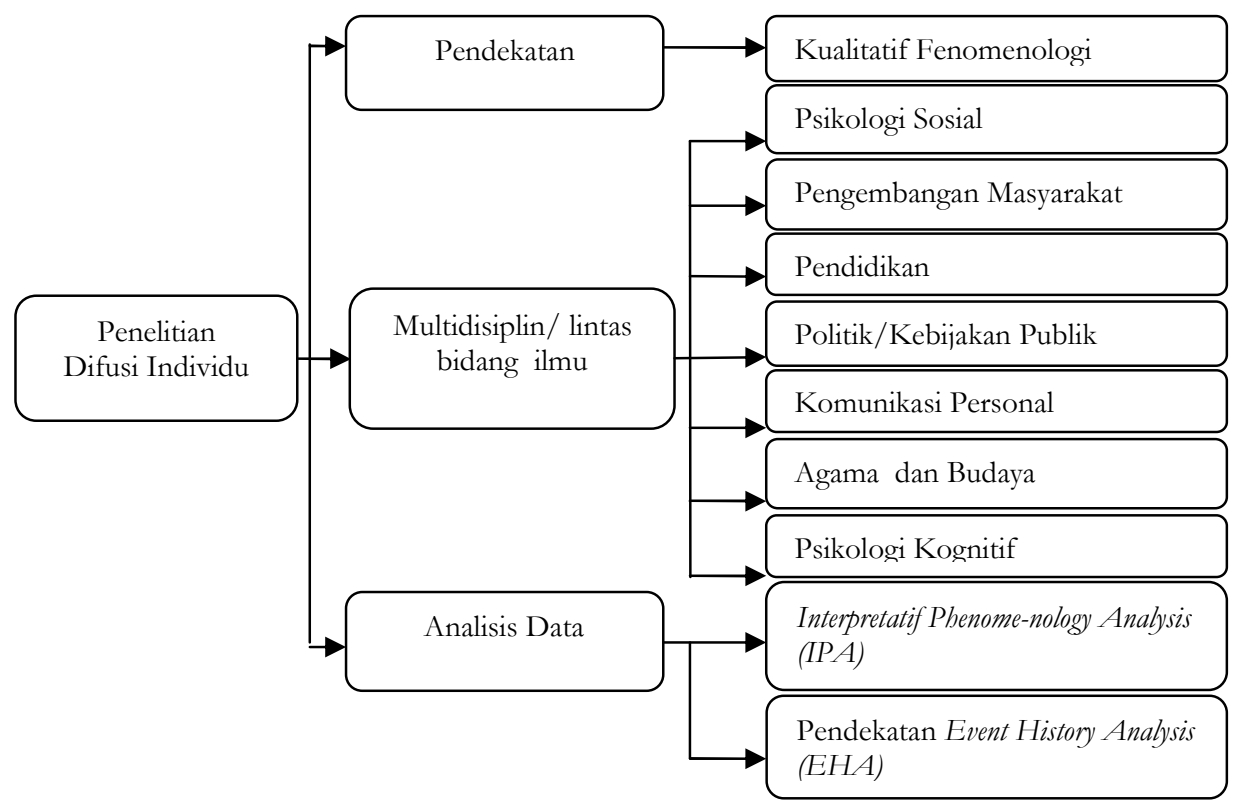

Gambar 6. Kompleksitas Penelitian Difusi Adopsi pada Individu

Penelitian pada individu untuk memahami secara mendalam proses menerima (adopsi) sebuah gagasan baru atau kebijakan baru merupakan proses yang kompleks. Penelitian difusi pada individu bermakna mema- 
hami proses mental yang terjadi. Menggambarkan proses mental pada individu-individu dalam penelitian difusi lebih tepat jika dilakukan dengan pendekatan kualitatif. Dengan pendekatan kualitatif, peneliti dapat mengeksplorasi proses mental pada setiap individu-individu dan menemukan tema-tema yang muncul dalam proses mental tersebut. Interpetative Fenomenology Analysis tepat digunakan dengan individu sebagai unit analisisnya. Individu sebagai unit analisis menjadi keharusan karena individu atau orang (people) merupakan salah satu dari tiga dimensi dalam implementasi kebijakan disamping tempat (place) dan kebijakan (policies). Studi difusi membutuhkan pemahaman secara mendalam pada perubahan yang terjadi pada setiap individu-individu dengan diterimanya informasi baru baik dalam kognisi maupun perilaku sehingga penelitian dengan pendekatan kuantitatif tak cukup bisa menjawab persoalan ini. Selain itu, untuk memahami difusi yang terjadi dalam proses mental individu membutuhkan kajian dari multi disiplin keilmuan. Berbagai bidang ilmu yang dibutuhkan untuk memahami proses difusi inovasi pada individu yakni ilmu komunikasi, psikologi, agama dan budaya masyarakat, politik, kebijakan, juga pendidikan. Ilmu pendidikan ini penting mengingat proses mendasar dalam difusi sebenarnya adalah proses belajar individu terhadap inovasi yang dinilainya sebagai baru dan relevan baginya untuk diadopsi.

Penelitian difusi pada individu memperhatikan individu-individu adopter dalam proses menerima atau menolak inovasi. Bagaimana individuindividu menerima informasi mengenai inovasi dan mengalami proses mental dalam dirinya sehingga menyatakan menerima atau menolak inovasi dan menunjukkan aktivitas untuk melaksanakan inovasi merupakan core dari penelitian pada individu. Hal ini relevan dengan yang dituliskan oleh Spillane etc (2006: 48) bahwa penting untuk memperhatikan kerangka kognisi individual selain dari kerangka kognisi sosial dalam studi difusi kebijakan. Kognisi merupakan lensa yang esensial untuk memahami implementasi kebijakan, terutama implementasi kebijakan yang membutuhkan perubahan yang signifikasi dalam kebiasaan. Honig (2006:17) menyatakan individu-individu merupakan mediator yang signifikan dalam difusi dan implementasi dengan cara-cara yang bervariasi. Individulah sebenarnya yang menjadi pusat dalam studi difusi maupun implementasi kebijakan. 
Kesetaraan dan keadilan gender merupakan kebijakan yang membutuhkan perubahan pada kebiasaan individu-individu baik kebiasaan berpikir, sikap maupun perilaku. Oleh karena itu, penggunaan perspektif kognitif sebagaimana yang dikemukakan oleh Spilane untuk memahami difusi kesetaraan dan keadilan gender fokus pada pentingnya distribusi perspektif kognitif dari individu-individu. Analisis perspektif ini membutuhkan pemahaman bidang ilmu psikologi terutama psikologi kognisi, psikologi perilaku dan psikologi sosial. Psikologi membantu memahami proses pembentukan sikap-sikap dan perilaku pada individu-individu serta bagaimana proses individu dipengaruhi dan mempengaruhi individu lainnya di dalam kelompok maupun diluar kelompok. Ilmu komunikasi juga penting untuk memahami difusi kebijakan karena pada dasarnya difusi merupakan bagian dari bidang ilmu komunikasi. Ilmu komunikasi membahas difusi kebojkan pengarusutamaan gender dari sudut pandang komunikasi personal yang terjadi pada individu-individu.

Difusi inovasi dalam masyarakat juga penting dipandang dari proses intervensi yang dilakukan oleh kelompok agent perubahan. Bahwa sasaran agen perubahan adalah individu-individu yang memiliki kapasitas sebagai orang-orang yang diharapkan mampu memberikan pengaruh dan perubahan (menjadi agen perubahan). Pemimpin atau tokoh-tokoh organisasi dalam penelitian menjadi sasaran agen perubahan global pada akhirnya menjadi agen perubahan dalam organisasi dan masyarakat di sekitarnya. Memahami masyarakat sebagai konteks perubahan individu-individu dan juga proses individu-individu tokoh atau pemimpin lokal memberikan perubahan juga menjadi bagian penting dalam studi terhadap proses difusi dalam masyarakat atau institusi. Untuk membahas hal tersbut ilmu tentang pengembangan masyarakat (community development) sangat diperlukan.

Di dalam proses difusi terjadi proses belajar individu-individu terhadap inovasi yang digulirkan. Dalam kerangka ini, penting pemahanam dari sudut pandang pendidikan terutama andragogi mengingat difusi kebijakan terjadi pada orang-orang dewasa dan proses belajar terjadi oleh karena kebutuhan pembelajar akan perubahan. Juga konsep pendidikan non formal atau pendidikan luar sekolah (masyarakat) merupakan bagian penting dalam memahami difusi kesetaraan dan keadilan gender. Konsep 
kesetaraan dan keadilan gender justru dimulai dari aktivitas pendidikan nonformal karena berkaitan dengan kehidupan masyarakat secara langsung. Jaringan nonformal dalam masyarakat lebih mendominasi.

Setiap individu akan mengalami proses yang berbeda dan unik serta memiliki alasan mengapa mereka menerima atau menolak inovasi. Oleh karena itu, peneliti difusi penting untuk memahamai latar belakang agama dan budaya masyarakat tempat difusi inovasi digulirkan. Bagaimanapun nilai-nilai dan norma-norma agama bagi individu maupun masyarakat menjadi dasar bagi mereka untuk bertindak dalam kehidupan sehari-hari. Agama dan budaya yang diikuti menjadi faktor penentu bagi diterima atau ditolaknya sebuah inovasi gagasan, program maupun kebijakan. Bidang ilmu agama dan budaya masyarakat harus dimiliki oleh peneliti difusi.

Studi difusi inovasi tidak terlepas dari konstelasi politik negara, apalagi inovasi kebijakan publik. Pemahaman terhadap situasi politik saat terjadinya difusi inovasi juga menjadi bagian penting untuk memahami proses difusi, dan pemahaman terhadap proses kebijakan. Studi difusi kebijakan merupakan bagian dari studi implementasi kebijakan yang merupakan bidang ilmu kebijakan. Jika keberhasilan implementasi kebijakan yang diharapkan maka memahami ilmu tentang kebijakan akan menjadi pendukung dalam studi difusi kebijakan.

\section{Simpulan}

Terdapat dua sumber informasi pengarusutamaan gender pada individu yakni sumber informasi individual dalam bentuk dua saluran yakni intrapersonal dalam pelatihan dan media dalam bentuk buku dan novel. Respon awal yang diberikan cukup bervariasi dari bingung, ragu-ragu, menolak, takut, dan ada juga yang langsung menerima karena gagasan kesetaraan dan keadilan gender dinilai dan dirasakan sebagai sesuatu yang baik, memberikan peluang dan memberikan pencerahan pada diri mereka. Hasil penelitian menunjukkan bahwa model konseptual difusi kebijakan pada individu ditemukan dengan tahap pengetahuan, persuasi, konfirmasi, keputusan dan implementasi. Model ini dapat menjadi model modifikasi dari Model Difusi Innovasi yang dikemukakan oleh Rogers. 
Penelitian difusi kesetaraan dan keadilan gender individu untuk memahami secara mendalam proses menerima (adopsi) sebuah gagasan baru atau kebijakan baru merupakan proses yang kompleks yang membutuhkan kajian interdisipliner berbagai bidang ilmu. Dengan pendekatan kualitatif, peneliti dapat mengeksplorasi proses mental pada setiap individu-individu dan menemukan tema-tema yang muncul dalam proses mental dengan analisis fenomenologi interpretatif (Interpetative Fenomenology Analysis). Difusi selalu terikat dengan durasi waktu tertentu hingga terjadi adopsi. Oleh karena itu, penggunaan Event History Analysis (EHA) dibutuhkan dalam penelitian difusi. Individu sebagai unit analisis dalam penelitian difusi menjadi keharusan karena individu atau orang (people) merupakan salah satu dari tiga dimensi dalam implementasi kebijakan di samping tempat (place) dan kebijakan (policies).

\section{Daftar Pustaka}

Damanpour, Fabiroz. 1996. Organizational and innovation: Developing and testing multiple contingensi s. Journal. Management Science, Vol. 42. No. 5 (may, 1996). Pp. 694-716. Published by www.jstor.org/stable/2634460.

Derbyshine, Helen. 2002. Gender manual: A practical for development policy maker and practitioners. Social Development Division of DFID. Published by www.allindiary.org/pool/resources/dfid-gender-manual.pdf.

Havelock, Ronald G. (tth). Planning for innovation: Through dissemination and utilization of knowledge. Michigan: Center for Research on Utilization of Scientific Knowledge.

Honig, Meredith I. 2006. Complexity and policy implementation challenge and opportunity for the field. Book chapter in New directions in education policy implementation: confronting complexity. New York: State University of New York. 
Honig, Meredith I. (Editor). 2006. New directions in education policy implementation: confronting complexity. New York: State University of New York.

Instruksi Presiden Republik Indonesia (INPRES) NOMOR 9 TAHUN 2000 (9/2000) Tentang Pengarusutamaan gender dalam pembangunan nasional.

Macdonald, Mandy., Sprenger, Ellen., \& Dubel, Iren. 1999. Gender dan perubahan organisasi. Yogyakarta: INSIST dan REMDEC.

Minister of Women Empowerment. 2002. The Manual of implemetation guidelines on gender mainstreaming in national development. as an annex of Circular of Minister of Women Empowerment no. B-89/Men.PP/ Dep.II/IX/2002, dated September 4, 2002.

Mosse, Julia Cleves. 1996. Gender dan pembangunan. Yogyakarta: Pustaka Pelajar dan Women Crisis Centre.

Ostrom, Elionor. 2007. Institutionsl rational choice: An assesment of the institutional analysis and development framework. Book chapter. In theories of the policy process. Ed. Paul Sabatier. California: Westview Press.

Rogers, Everett M. 1995. 2003. Diffusion of innovations. New York: The Free Press.

Sabatier, Paul A. (Editor). 2007. Theories of the policy process. California: Westview Press.

Sabatier, Paul A. 2007. The need for better theories. Book chapter in Theories of The Policy Process. Edited by Paul Sabatier. California: Westview Press. 
Smith, Jonathan A., Flowers, Paul., \& Larkin, Michael. 2009. Interpretative phenomenological analysis: Theory, method and research. Los Angeles, London, New Delhi, Singapore, Washington: Sage.

Smith, Jonathan A. (ed.). 2009. Psikologi kualitatif: Panduan praktis metode riset. Terjemahan dari Qualitative Psychology A Practical Guide to Research Method. Yogyakarta: Pustaka Pelajar.

Spillane, James. P., Reiser, Brian J., Gomez, Louis M. 2008. Policy implementation and cognition: The role of human, social, and distributed cognition in framing policy. Book chapter in New directions in education policy implementation: confronting complexity. New York: State University of New York.

Stewart, Ann. 2004. Aspiration to action: 25 years of the women's convention (Cedaw). United Kingdom: British Council.

Walker, Jack L. 1969. The diffusion of innovation among the American States. The American Political Science Review, Vol.63, No. 3 (Sept. 1969), 880-899. Published by: American Political Science Association Stable URL: http://links.jstor.org/

Yalcinkaya, Goksel. 2007. Understanding the emergence of aggregate level innovation diffusion through individual level. Dissertation. USA: Michigan State University. Publish by: gradworks.umi.com/32/82/ 3282232.html. 